\title{
IMPACT OF THE CAPITAL MARKET ON THE TRANSFORMATION OF THE ECONOMY IN UKRAINE
}

\author{
Stanisław Krupka \\ Institution of Theory of Finances, Dept of Economics, Economics University in Opole, \\ ul.Ozimska 46 a, Opole 45-058, Poland.E-mail:skrupka@uni.opole.pl
}

Received 28 Aug 2006; accepted 25 July 2007

\begin{abstract}
The paper is dedicated to a thorough analysis of the formation of the securities market in Ukraine, which follows the hash transitional road to market economy full of political vibes and the fight of interest groups reflected in the so-called "grey" or "black" economy. Therefore the path to developing the market of securities in Ukraine was not easy. An overview of the related laws and directives passed in Ukraine is presented with the author's comments, suggestions and scientific reasoning of how the market of securities developed then and what are the prospects for the future. With this purpose in mind, the author presents data on the legal efforts of the Ukrainian Government to prepare a fruitful soil for the development of securities market and discussed the obstacles, which posed and still pose threats for an adequate functioning of the Ukrainian market of securities. Some European comparisons are taken into account, especially from the Frontier's group countries.
\end{abstract}

Keywords: capital market, market of securities, economy in transition, Frontier's group, Ukraine.

\section{Introduction}

In Ukraine, as in other countries of Commonwealth of Independent States (CIS), at the time of the former Soviet Union, the market of securities was noticed as the system of the capitalistic mechanisms, which isolated capital resources from production with the intention to use them for speculating purposes. In the course of time nobody had probably any doubts that the market of investment is a powerful lever for developing national economy, a factor mobilising economy and crucial in those fields of economy which make the highest profits.

Ukraine entered the rough road of social reforms in the 1990 s, when globalisation processes all over the world took place especially in economy [1]. This article aims to follow the developments in the market of securities in Ukraine in 1991-2004, producing the evidence to the rise of the need for a systematic approach to the formation of such capital market. The methods applied in the paper are comparative and historical.

\section{A pathway to create the market of securities in Ukraine, 1991-2004}

To create the market of securities Ukraine used the experience of developed countries and thus created its own history of the civilised market. The moment of passing the law "About Securities and Exchange” in 1991 ("Про ичінні папери і фондову біржу. Закон України від 18.06.91 p. № 1201-XII.") [2] can be considered as the beginning of the market of securities in Ukraine.

In 1992-93, first stockbrokers appeared and the Ukrainian Stock Exchange (1991) started to operate. The next stage of development of the Ukrainian market of securities is the privatisation of state enterprises in 1994-96. It was possible due to the adoption of the following bills: "The Directive of the Cabinet of Ministers", "On fiduciary funds" and finally "On funds and investment companies" [3]. During the accumulation of investment certificates, a certain sum of investment funds and fiduciary was collected. As a result, Capital Stock Exchange came into being with Kiev's International Stock Exchange, Donieck Stock Exchange and companies which united the participants of such capital market companies as the Capital-Trade System (the PFTS (ПФТС) - Периа Фондова Торговельна Система), the Ukrainian association of investment business, the professional participants of market and the deposit system.

The creation of the Capital Market and the State Committee of Securities (PKPWiRK (ДКЦПФР) - Державна комісї з цинних паперів та фондового ринку) іn 1995 can be considered as an important step in developing the securities market in Ukraine [4]. The next important step is the adoption of the law "On the State regulation of securi- 
ties market in Ukraine" (the Order of the President of Ukraine) [5]. National regulation permitted settling the activities of participants of market in some parts.

The present stage of the securities market has its form since 1997. The interest in the market on the part of foreign investors permitted developing the secondary market of securities, which caused the increase in prices of the Ukrainian companies remittent as well as the volumes of trade on stock.

The financial crisis in 1997 brought a sharp decrease in foreign investments in Ukrainian securities, which led to a huge drop in the rate of shares.

Increase in the privatisation processes and the quantity of joint-stock companies, the enlargement of contained contracts of purchase-sale of shares can be noted down. It led to the enlargement of registration activity of the PKPWiRK then. In 1997, PKPWiRK passed 156 licenses on activity [6]. Depositary institutions appeared [7]. The volume of turnover went up on the capital market, but the volume of turnover was dominated by the sale of shares with the funds of property of state, the turnover on the secondary-market almost did not exist.

In 1997, the first Ukrainian stock index appeared as well as stock broking houses. Since 1997 the Ukrainian market of securities suffered many problems, the reasons of which are:

- Firstly, it can be explained by a poor quality of almost all securities which are quoted on the market.

- Secondly, the rotation of Ukrainian capital market is on a low level. It can be explained by difficult financial situation of companies, high debts and also by a large participation of state treasure in the majority of joint-stock companies.

The deficit of the Ukrainian capital market can be connected with the lack of economic-social stability in the state life, as well as with a very weak development of the primary market.

In 1999, the Ukrainian market of securities was characterised by downward tendencies. It was related to some causes:

1. The crisis of the Russian capital market, because the majority of foreign capital on the Ukrainian market came from Russia.

2. An increase in the attractiveness of the OWDP. OWDP was the investors' alternative aim, including the calculation of higher risk of investing in stocks; capital began to flow from the market to OWDP market.

3. Certain political instability was also a problem.

The foreign investors scared away by a political crisis as well as Asian crisis began to withdraw the capital from Ukraine in autumn 1997.

In 1999, the emission of shares was reduced in comparison with the previous years. This phenomenon can be explained by the final stage of privatisation. The volume of turnover on the secondary market of securities was low, which can be explained by the lack of money equivalent

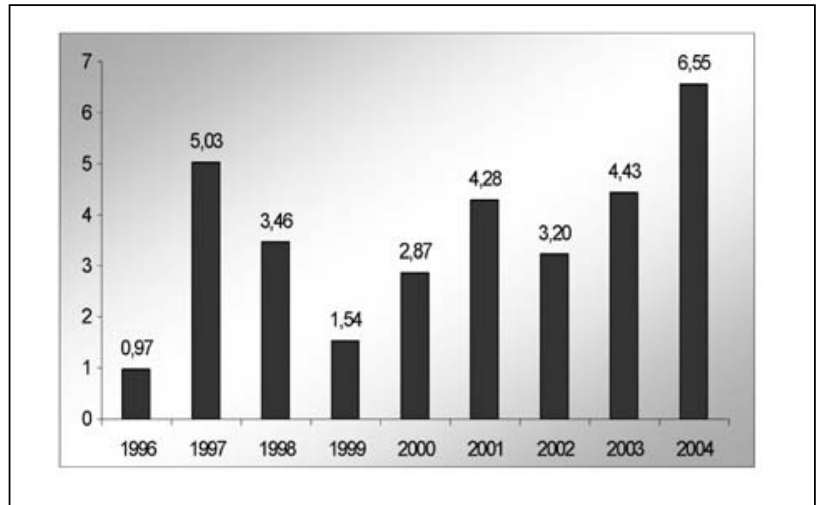

Source: [9]

Fig 1. Size of emission of securities in Ukraine, 1996-2004 (in USD bn)

and a weak economic situation. The real size of costs accounted for only $18,6 \%$ of the size of emission. Many jointstock companies did not finish the privatisation processes and this situation did not permit them for additional emissions [8]. Besides, new owners were afraid to make efforts in taking over all enterprises and they did not start additional emissions.

The market of securities in Ukraine (Fig 1) during 19962004 was developing almost only due to privatisation, the secondary emission was fledging. It should be noticed that until the increment of capitalisation is not supported by secondary emission and the growth of shares, the capital market will be not the source of investment. Moreover, the balanced development of market of securities depends on the real sector of economics.

The situation in Ukraine became ambiguous when practically a state or corporate market of indebted securities did not exist. Experiments with emission of OWDP which was the copy of Russian model of the state with indebted securities came to a full crash [8]. That collapse for the Ukrainian economy was not so painful in comparison with the Russian one. However, Ukraine is one of hardly any state in the world whose budget deficit is covered by the help from outside the country. This situation is abnormal.

We can distinguish the second period, which was in 1999 and which is seen as a breakthrough in dynamics of the securities' market. We can observe: the acceleration of economy due to influence on pre-election money, improvement of external trade balance and activation of protection remedies. The great influence on the increase of Ukrainian economy had the developing Russian economy after devaluation.

At the end of 1999 the structure of market improved considerably: in December, the number of bank bills in general rotation decreased to $3 \%$, in comparison with $11-$ $12 \%$ in October-November or $33 \%$ in July [10]. In relation to the disappearance of primary and secondary OWDP's market, the turnover of these securities on PFTS disappeared in fact. Numerous agreements on corporate securities were concluded. 


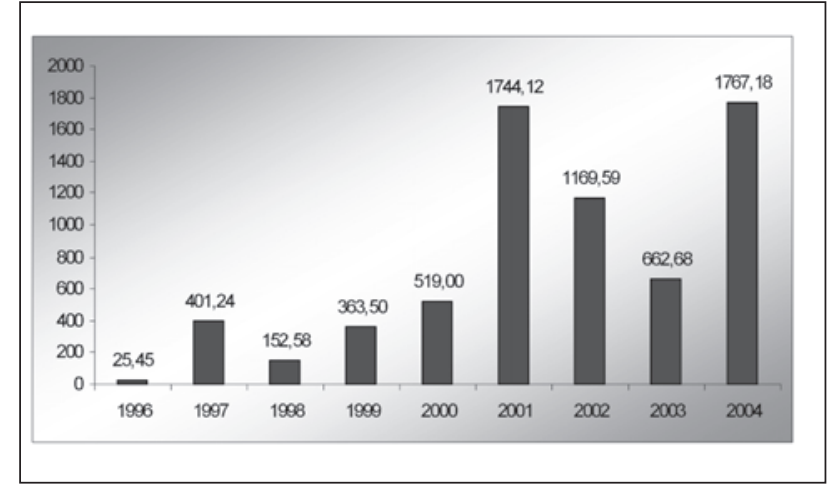

Source: [9]

Fig 2. Size of turnover on the organised guided capital market in Ukraine, 1996-2004 (USD mln)

The size of rotations on the organised capital market (Fig 2) shows the character of market' securities in Ukraine.

In 1996, this came into being; 1997 was the beginning of the developing market with the help of foreign investment capital, which was withdrawn at the end of 1997; 1998-1999 - time at which there was the breakdown of the market, which was caused by two waves of financial crisis (second period of 1997 and the end of 1998). The beginning of a dynamic increase comes to the second half of 1999, which yielded fruit of positive turning-point in 2000. In 2001, the market of securities reached its maximum level against all the previous years - 9241,188 mln HR (1744,116 mln USD) [11]. Next years we noticed a tendency to decrease rotations size which went down to the lowest level in 2001-2004, which was caused by a low level of the market efficiency (companies mostly dealt with mergers and interceptions but did not have any income) and levied the FATF sanction on Ukraine (it was caused by snapping author's license and mass, illegal production of pirate CD and DVD-discs). The year of 2004 can be named a crucial year for the history of Ukrainian organised guided capital market. The size broke a record level from 2001 and reached 9,38 bn HR (1,767 bn USD). It was caused by the acceleration of the Ukrainian economy, disconnection of Ukraine from "black conspiracy" FATF and chartered a state status with the market economy for Ukraine.

Nowadays, the actors on organised capital market are ten SRO (ie self-regulated organisation) which have the authority to lead operations on the market, 8 markets which are active on stock market and 2 TIS (i.e Trade and Information Systems), which operate on the market behind-stock. The size of turnover on stocks and TIS are placed in Table. The composition of regulated market is as follows [12]:

Stocks:

- KISE (KMФБ) - Kiev International Stock Exchange;

- DSE $(\triangle \Phi Б)$ - Donetsk Stock Exchange;

- PSE (ПФБ) - Prydniprovsky Stock Exchange;

- UIBCE (УMBБ) - Ukrainian Inter-Bank Currency Exchange;

- UISE (УМФБ) - Ukrainian International Stock Exchange;

- USE (УФБ) - Ukrainian Stock Exchange;

- CSE (КФБ) - Crimean Stock Exchange;

- LSE $(\Lambda Ф Б)$ - Lugansk Stock Exchange.

Trade and Information Systems [13]: a) PFTS (ПФТС) - First Stock Trading System, b) PTIS (ПТІС) The South-Ukrainian Trade and Information System. The Ukrainian Stock Exchange - USE (УФБ), is an exchange which is developing in the most dynamical way. Its size of turnover in 2004 was 1,5 bln HR (283,15 mln USD). It is worth noticing that other organisations which were active on the stock market, with a few exceptions, represent a very similar level (KISE, DSE, UIBCE, LSE). Next, the organisations can be classified as marginal having no great influence on the whole Ukrainian Capital Market.

The size of turnover in the First Capital-Trading System (PFTS (ПФТС)) for one year enlarged from $998 \mathrm{mln}$ HR (189,49 mln USD) to 1,46 bn HR (269,9 mln USD). Next years we see the tendency of yearly increasing of turns size in PFTS, which almost caused the monopolisation of Ukrainian capital market by PFTS. It occupies currently

The size of turnover on Stock and TIS in 1996-2004 (USD mln)

\begin{tabular}{|c|c|c|c|c|c|c|c|c|c|c|c|}
\hline \multirow[b]{2}{*}{ Years } & \multicolumn{11}{|c|}{ Stock and TIS } \\
\hline & $\begin{array}{c}\text { KISE } \\
\text { (КМФБ) }\end{array}$ & $\begin{array}{c}\text { DSE } \\
(\triangle \Phi Б)\end{array}$ & $\begin{array}{c}\text { PSE } \\
(П Ф Б)\end{array}$ & $\begin{array}{l}\text { UIBCE } \\
\text { (УMBБ) }\end{array}$ & $\begin{array}{c}\text { UISE } \\
\text { (УМФБ) }\end{array}$ & $\begin{array}{l}\text { USE } \\
\text { (УФБ) }\end{array}$ & $\begin{array}{c}\text { CSE } \\
(\text { КФБ) }\end{array}$ & $\begin{array}{l}\text { LSE } \\
(\Lambda \Phi Б)\end{array}$ & $\begin{array}{c}\text { PFTS } \\
\text { (ПФТС) }\end{array}$ & $\begin{array}{l}\text { PTIS } \\
\text { (ПТIC) }\end{array}$ & $\begin{array}{c}\text { Toge- } \\
\text { ther: } \\
\text { Stock } \\
\text { and TIS }\end{array}$ \\
\hline 1996 & 0,05 & 0,09 & & 6,97 & & 16,70 & & & 1,65 & & 25,45 \\
\hline 1997 & 2,48 & 1,13 & & 200,86 & & 12,17 & & & 184,59 & & 401,24 \\
\hline 1998 & 8,11 & 6,65 & & 22,41 & & 14,63 & & & 98,79 & & 152,58 \\
\hline 1999 & 16,22 & 7,76 & 4,63 & 82,93 & & 60,09 & & & 189,49 & 0,21 & 363,50 \\
\hline 2000 & 22,77 & 38,84 & 1,43 & 142,58 & & 42,92 & 0,80 & & 269,21 & 0,45 & 519,00 \\
\hline 2001 & 12,09 & 0,55 & 0,70 & 523,18 & 6,86 & 13,64 & 0,89 & & 1186,20 & 0,04 & 1744,12 \\
\hline 2002 & 22,81 & 2,20 & 0,42 & 14,78 & 5,05 & 3,16 & 0,79 & & 1176,39 & 0,24 & 1169,59 \\
\hline 2003 & 7,06 & 37,11 & 0,06 & 1,60 & 2,41 & 7,66 & 1,62 & 1,59 & 603,26 & 0,31 & 662,68 \\
\hline 2004 & 43,33 & 399 & 6,06 & 35,83 & 4,79 & 283,15 & 3,88 & 30,91 & 1319,43 & 0,66 & 1767,18 \\
\hline
\end{tabular}

Source: own compilation from [9] 
$74,66 \%$ of market, the size of turnover on PFTS mounted to about 7 bn HR $(1319,49$ mln USD), which was an unreachable level for the other stocks. It is worth noticing that PFTS belongs to the off-stock market. In 2000, the PFTS started transmission of news in on-line mode.

The main event for Ukrainian capital market was the creation, in 2000, its own depository - VAT "Ukrainian depository" [7], [14].

The status analysis of development of Ukrainian securities market shows that many important problems have been solved. Nowadays such problems are:

- the lack of developed national accounting-stock system of transactions;

- imperfection of the taxation of operation with securities;

- the absence of perfect control system over the market;

- slow development of national infrastructure of market securities, especially of the deposit system which is too small as on market's necessities;

- the lack of information for the society about the market's activity of securities.

Unregulated market of securities in Ukraine is much bigger than the regulated one. Such a situation cannot be found in any East European country. It caused the lack of competitiveness of the real price, which misled investors. It is almost known that all the rates of the national market are enumerated on the basis of parameters of the regulated market, and investors from Western countries can have a view that Ukrainian market is small and unprofitable.

The acceleration of the economic reforms, growth of meaning of capital market in reaching the investments in the Ukrainian economy are facilitated and strengthened by the Decree of President of Ukraine "On additional sources of development of capital market in Ukraine" [15]. In the appendix B "On basic directions of development of capital market", in the Decree of President we can find mechanisms to enlarge its development; they should serve for developing market tax relieves.

For example:

- Tax-free policy for profitable enterprises and also exemption from the VAT tax for non-commercial (unprofitable) enterprises of the capital market.

- The inclusion to the remittent rate of issue income of income with a renewed distribution of securities over the price of ransom of such securities.

- The abolishment of treasury payment on registration information of new securities.

- The abolishment of taxation of rate difference, resulting from the rate of the foreign investor's currency which comes in from foreign currency to national one.

- The abolishment of taxation on property and costs of an enterprise.

- The use of tax service for protecting the participant's debt, which takes part on capital market, and also in not crossing the double size of debts.

\section{Ukrainian capital market in comparison with other developing markets}

The basic source of information about the capital markets in countries, which are developing, for international investors are files which are collected and widespread by international ranking agency Standard \& Poor's.

In Standard \& Poor's classification, Ukraine appeared in Frontier markets' group (border market), in which apart from Ukraine there were 20 other states, such as Romania, Slovenia, Slovakia, Croatia, Bulgaria, Estonia, Lithuania, Latvia etc.

Estimating the development state of the Frontier market group, Standard \& Poor's for capital markets of every country of this group marks the row of coefficients (the capitalization of market (Table 2), the coefficient $\mathrm{P} / \mathrm{E}$ and $\mathrm{P} / \mathrm{BV}$ ) and the indexes S\&P /IFCG [16]. All these coefficients, which show the status of capital market in Ukraine, the Standard \& Poor's are based on PFTS' files. In Ukraine, this place is reserved for PFTS, but we must notice that PFTS takes part on Off-stock market, but is absent on stockexchange, as GPW.

When we compare files from the Standard \& Poor's, coefficients of Ukrainian capital market in comparison with files from new, independent Frontier's group countries, we can notice:

- In 2004, Ukraine took the first place in Frontier's group with the index growth of S\&P/IFCG whose value was about $170,33 \%$. The second and the third places in this group with the index growth $\mathrm{S} \& \mathrm{P} /$ IFCG took Slovakia (129,3\%) and Romania $(100,13 \%)$. As the analyst maintains, the catalyst's role of increase in the Ukrainian and Romanian indexes was played by elections, in which democratic forces won. It is worth noticing that in 2004 the 'basket' marking index of the S\&P/IFCG-Ukraine included the securities of opened joint-stock companies, VAT - Vidkryte Akcionerne Towarstvo ("open joint-stock company"), companies such as „Ukrtelekom”, „Kyivenergo”, „Ukrnafta”, „Zakhidenergo”, „Tsentrenergo”, „Dniproenergo”, „Stirol”, „Nyzhnodnipropetrovsk Piping” and „Azovstal”.

- By the level of capitalisation, Ukraine comes second just after Romania. Enumeration of capitalisation coefficient of the Standard \& Poor's did not include calculation of the securities which are found in state property, and had a great influence on the capitalisation level in Ukraine.

- The size of turnover on the organised capital market in Ukraine is an average. The main cause of the differences between Ukraine and other countries from Frontier group is the so-called "concentration law", according to which the circulation of securities occurs exclusively on the organised capital market. 


\section{Conclusions}

The present approach to privatisation is not favourable for developing the capital market in Ukraine. Now, when the country sells the most curious companies exclusively for strategic investors' money, the society is devoid of obtaining even some parts of these companies. Without paying attention to financial possibility, small investors have not got any chance to appear on the capital market. The lack of free share turnover on the secondary market of securities entails inefficiency of these companies. One of the most important efficiency rates of the company in the economy is the rate of the height of campaign notation of a given company.

The total superiority of material figure of securities does not permit using fully present technologies of the depository's person, which makes the market not enough interesting and secure.

The main tendencies on international capital markets, which will mark the further road of development of Ukrainian capital market, are:

- Globalisation of worldwide capital market, creation of global commercially - accounting systems for service of international capital markets;

- Growth of significance of the latest communicative computer technologies in the process including the transaction on international capital market;

- Universalisation of activity of financial institutions;

- Increase in the institutional investors' significance of capital investments;

- Internationalisation and regionalisation of frames of legal capital markets.

The main aim of functioning and developing the capital market in Ukraine should become the pressure of investment potential on renovation and the protection of the enterprise growth.

The dynamic, transparent market of securities has to protect the realisation of national businesses of Ukraine and favouring the strengthening the state economic independence. This market should:

- be in favour of coming the investments into the real sector of economy;

- create the effective systems of protecting laws and investors' businesses of both foreign investors as well as the national ones;

- create convenient conditions for developing common investing institutions, exclusively the non-state pension funds;

- enlarge the national system of contracts concluding with securities or property laws for them;

- broaden the effective system of trade prosecution which is to mark the real value of written down securities;

- concentrate and centralise the turn of securities of Ukrainian emittents on regulated market aiming to obtain the competitiveness;

- create conditions for the growth of competitiveness of Ukrainian market, exclusively with the growth of its value on international arena;

- harmonise the policy of state to capital market with monetary-credit, only monetary or fiscally-budgetary policy with the aim to increase the capital market value in country economy.

\section{References}

1. BAJURA, D. The mechanism of wealth creation, when not working. Украинская инвестиционі газета, 14 Nov 2000, No 45 (in Russian).

2. On securities' prices and stock exchange funds. The Ukrainian Law of 1806 91, No 1201-XII (in Ukrainian).

3. The situation on investment funds for private companies. Order of the Ukrainian President of 1902 94, No 55/94 (in Ukrainian).

4. PETRUNIA, J. E. Non-professional subjects in the Ukrainian stock market. Kiev: Publishing House "Knowledge", 1999 (in Ukrainian).

5. On the fundamentals of investment policy for 1999-2001. Order of the Ukrainian President of 1808 99, No 1004/99 (in Ukrainian).

6. DANILOV, O. D.; IVASHINA, G. M.; CHUMACHENKO, O. G. Investments. The Guide-book. Kiev: Publishing House "Computer-press", 2001 (in Ukrainian).

7. On national depository system in the case of internet application in stock exchange process in Ukraine. Order of the Ukrainian President of 1012 97, No 710/97-BP (in Ukrainian).

8. PAVLOV, V. I.; PILIPENKO, I. I.; KRIVOVZIACHIUK, I. V. The price of securities in Ukraine. The Guide-book. Kiev: Publishing House „Condor”, 2004 (in Ukrainian).

9. The Ukrainian Investment Daily, 2002, № 5 (in Russian).

10. SUCHANOV, V. V.; ZAVALNIA, Z. V.; STARINSKY, M. V. Legal regulation of securities in Ukraine. The Guide-book. Sumi: Publishing House "Universal Book", 2005.

11. Business, No 6, 5 Febr, 2002 (in Russian).

12. On supplementary comments on development of fund market in Ukraine. Order of the Ukrainian President of 2603 2001, No 198/2001 (in Ukrainian).

13. On the situation of the order of restoring the issuing of stocks and bonds and their emission. Official Directive of Capital Market and the State Committee of Securities of Ukraine, 120298 , No 36 (in Ukrainian).

14. On amendments in acting laws of Ukraine to stimulate the investment activities. Order of the Ukrainian President of 1506 99, No 977 (in Ukrainian).

15. On the institution of mutual investment (Shares of corporate investment funds). Order of the Ukrainian President of 1503 2001, No 2299-III (in Ukrainian).

16. On the book-keeping standard-12 "Financial Investments". Official Directive of the Ministry of Finance of Ukraine, 26042000 , No 91, approved by the Ministry of Justice of Ukraine on 1705 2000, No 284/4505 (in Ukrainian). 


\section{KAPITALO RINKOS ITAKA UKRAINOS EKONOMIKOS TRANSFORMACIJAI}

\section{S. Krupka}

Santrauka

Straipsnyje pateikiama Ukrainos vertybinių popierių rinkos, kaip vienos iš kapitalo rinkos, formavimo istorinè lyginamoji analizė, apimanti 1991-2004 metus. Daug dèmesio skiriamas Ukrainos Vyriausybės pastangoms kurti teisinį vertybinių popierių rinkos pagrindą, apžvelgiami istatymai ir direktyvos, teikiamos tolesnės šios rinkos plètros tendencijos.

Reikšminiai žodžiai: kapitalo rinka, vertybinių popierių rinka, pereinamoji ekonomika, Frontier šalių grupė, Ukraina.

Stanisław KRUPKA. Adjunct, the Economics University in Opole (Poland). Fields of scientific interests include macroeconomics, financial management, monetary policy, securities. 